\title{
Low-pressure, water-assisted anatexis of basic dykes in a contact metamorphic aureole, Fuerteventura (Canary Islands): oxygen isotope evidence for a meteoric fluid origin
}

\author{
M. I. Holloway · F. Bussy • T. W. Vennemann
}

Received: 23 January 2007/Accepted: 8 June 2007/Published online: 6 July 2007

(C) Springer-Verlag 2007

\begin{abstract}
Migmatites produced by low-pressure anatexis of basic dykes are found in a contact metamorphic aureole around a pyroxenite-gabbro intrusion (PX2), on Fuerteventura. Dykes outside and inside the aureole record interaction with meteoric water, with low or negative $\delta^{18} \mathrm{O}$ whole-rock values $(+0.2$ to $-3.4 \%$ o $)$, decreasing towards the contact. Recrystallised plagioclase, diopside, biotite and oxides, from within the aureole, show a similar evolution with lowest $\delta^{18} \mathrm{O}$ values $(-2.8,-4.2,-4.4$ and $-7.6 \%$, respectively) in the migmatite zone, close to the intrusion. Relict clinopyroxene phenocrysts preserved in all dykes, retain typically magmatic $\delta^{18} \mathrm{O}$ values up to the anatectic zone, where the values are lower and more heterogeneous. Low $\delta^{18} \mathrm{O}$ values, decreasing towards the intrusion, can be ascribed to the advection of meteoric water during magma emplacement, with increasing fluid/rock ratios (higher dyke intensities towards the intrusion acting as fluid-pathways) and higher temperatures promoting increasing exchange during recrystallisation.
\end{abstract}

Keywords Basic dykes - Contact aureole - Meteoric water · Oxygen isotopes · Partial melting

Communicated by J. Hoefs.

Electronic supplementary material The online version of this article (doi:10.1007/s00410-007-0230-8) contains supplementary material, which is available to authorized users.

M. I. Holloway $(\bowtie) \cdot$ F. Bussy $\cdot$ T. W. Vennemann Institute of Mineralogy and Geochemistry, Anthropole, University of Lausanne, 1015 Lausanne, Switzerland e-mail: Isabelle.Holloway@unil.ch

\section{Introduction}

Partial melting of basic igneous rocks in low-pressure contact metamorphic environments is a rarely documented phenomenon, as geological settings combining a high heat flow and shallow crustal levels, are uncommon. This process is, however, likely to occur at mid-ocean ridges and in oceanic plateaus (LIPs; Large Igneous Provinces). Flagler and Spray (1991) document anatectic plagiogranites in amphibolitised gabbros from oceanic fragments within high temperature shear zones, near a spreading centre in the Shetland Islands. Bédard (1991) and Mevel (1988) also report occurrences of anatexis in oceanic crust or related units. However, the in situ anatexis of basic rocks in an ocean island setting has, to our knowledge, only been described in Fuerteventura Basal Complex (Hobson et al. 1998, 2000).

The Basal Complex of Fuerteventura, Canary Islands, represents the hypabyssal root zone of an ocean island volcano, exposure of which can be attributed to uplift and subsequent erosion of the overlying formations. This complex records a long magmatic activity characterised by the intrusion of numerous magma batches as small plutons, dykes, dyke swarms, and ring-dyke complexes of alkaligabbros, pyroxenites, syenites and carbonatites (Cantagrel et al. 1993; Demény et al. 1998; Hoernle et al. 2002). The high heat flow generated by the successive magma pulses feeding the overlying subaerial volcanic centres induced metasomatic and metamorphic processes, culminating with the migmatisation of basic dykes around two layered pyroxenite-gabbro intrusions called PX1 and PX2 (Stillman 1987).

The PX2 migmatised dykes are characterised by a dense network of closely spaced millimetre-wide leucocratic segregations with perfectly preserved, comb-like, igneous textures. Mineralogically these migmatites consist of 
diopside, andesine plagioclase, Ti-rich biotite, ilmenite, magnetite and minor apatite. They are dominated by plagioclase in the leucosome and diopside in the melanosome. They contain about $25 \%$ of leucosomes, considered to represent the original amount of melt present.

Pressure conditions during anatexis are difficult to assess, as no suitable mineral associations are available. An upper bound can be fixed at ca. $4 \mathrm{~kb}$, which corresponds to the present depth of the Moho under the Fuerteventura-Lanzarote ridge (about $11 \mathrm{~km}$; Banda et al. 1981), but as some of the Basal Complex intrusions were emplaced into overturned ocean-floor sediments, the depth of intrusion was probably much lower than this, roughly estimated at 3-6 km, i.e., ca. $1-2 \mathrm{~kb}$, approaching the maximum depth of most known meteoric-hydrothermal systems (e.g., Nabelek 1991).

Temperature estimates for the shallow level partial melting event, around the PX1 intrusion, are in the order of $820-890^{\circ} \mathrm{C}$, based on orthopyroxene-clinopyroxene and amphibole-plagioclase thermometry (Muñoz and Sagredo 1994). However, low pressure (2 kb) partial melting experiments on ferrogabbros from the PX1 country rock performed by Koepke et al. (2003), require temperatures up to $1,000^{\circ} \mathrm{C}$ in order to produce 25\% melt (Fig. 3a, Koepke et al. 2003). These experiments also highlight the importance of water in the process of partial melting: at $1,000^{\circ} \mathrm{C}, 2 \mathrm{~kb}$, and the addition of $0.3 \mathrm{wt} \%$ water, only a few percent of melt was produced. The $25 \%$ melt observed in the PX2 migmatised dykes would require the addition of approximately $2.7 \mathrm{wt} \%$ water. Hence, a large amount of fluid is necessary to produce such a high degree of partial melting. The source of the fluids could have been meteoric, oceanic, or magmatic, either in circulation at the time of anatexis or released by hydrous lithologies upon heating from the PX2 intrusion.

Oxygen isotopes are a powerful tool for deciphering fluid histories, i.e., sources and flow paths, in contact metamorphic environments, provided $\delta^{18} \mathrm{O}$ values of the protoliths and the fluid are sufficiently different (e.g., Valley 1986; Roselle et al. 1999). Ocean island basalts have fairly heterogeneous $\delta^{18} \mathrm{O}$ values ranging from 4.6 to $7.5 \%$ (Hoefs 1997), although most are around 5.5\% (Harmon and Hoefs 1995). In the Canary Islands the relatively large range has been attributed to recycling of ancient hydrothermally altered oceanic crust (causing ${ }^{18} \mathrm{O}$ depletion in the rock and lowering of the assumed primitive mantle $\delta^{18} \mathrm{O}$ values of 5.5-6.0\% ) and crustal contamination (causing enrichment) (Thirwall et al. 1997). The tracing of magmatic fluid flow by means of oxygen isotopes can be an extremely subtle affair in a system where the intrusion and its country rock are both basic and igneous. However, the influence of sea or meteoric water, with their low or negative $\delta^{18} \mathrm{O}$ values, respectively, could be more easily tracked.

Oxygen and hydrogen isotope studies on gabbros and dykes, all metamorphosed under static greenschist facies conditions, from the Basal Complex around Pajara, were done by Javoy et al. (1986). They obtained mean wholerock $\delta^{18} \mathrm{O}$ values of $+1.5 \pm 0.3 \%$ for dykes and $+4.0 \pm 0.6 \%$ or plutonics, arguing that isotopically light meteoric water must have been present at the time of dyke emplacement. This assumption would require high altitude precipitation in order to further fractionate the composition of predicted Tertiary meteoric waters from the palaeolatitudes of the Canary Islands, thus suggesting the former existence of volcanic edifices as high as ca. 2,500-4,000 m in elevation (Javoy et al. 1986).

The aim of this study is to investigate the nature and origin of the fluids that assisted the low-pressure anatexis of basic dykes in the aureole of the PX2 intrusion, using oxygen isotope values measured for whole-rocks and mineral-separates from within and beyond the aureole.

\section{Geological setting}

Fuerteventura is one of the easternmost islands of the Canary archipelago (Fig. 1a), a chain of Early Miocene to recent volcanic islands that lie on oceanic crust ranging in age from ca. 150 to $175 \mathrm{Ma}$ (Schmincke et al. 1982), about $100 \mathrm{~km}$ off the north-western coast of Morocco. Two major lithologic units have been distinguished on the island (Fig. 1b): the Basal Complex (BC), and the unconformably overlying Subaerial Volcanic Series of flat-lying flows of Neogene and Quaternary ages.

The Basal Complex (e.g., Fúster et al. 1968; Stillman et al. 1975; Stillman 1987; Le Bas et al. 1986) consists of a thick Mesozoic sedimentary sequence overlain by Tertiary volcanic sedimentary rocks of Oligocene age, intruded by a very dense, early Miocene (e.g., Coello et al. 1992; Cantagrel et al. 1993), NNE-SSW-trending sheeted dyke complex, which formed in association with the emplacement of a series of nested alkaline plutons. The 'Tierra Mala' pluton [a series of alkali pyroxenites, hornblendites, gabbros and syenites $(G, M$ and $S$ in Fig. 1b)], followed by the 'Ajuy-Solapa carbonatite complex' [a series of apatite pyroxenites, ijolites, syenites, carbonatites and fenites $(C$ in Fig. 1b)] (Cantagrel et al. 1993; Le Bas et al. 1986; Balogh et al. 1999), were intruded by the PX1 vertically layered, alkali-gabbro and pyroxenite intrusion (Fig. 1), causing the metamorphism and partial melting of dykes in its aureole. The second layered gabbro-pyroxenite intrusion, PX2, was emplaced along the SE margin of PX1 and caused the partial melting of dykes intrusive to PX1. The youngest intrusion in the Basal Complex, with a mean age of $20.6 \pm 1.7 \mathrm{Ma}$ (proposed by Le Bas et al. 1986), is the Vega de Rio de Palmas ring complex [a syenitic ring dyke with a central alkali gabbro stock ( $V$ and $T$ in Fig. 1b)]. 


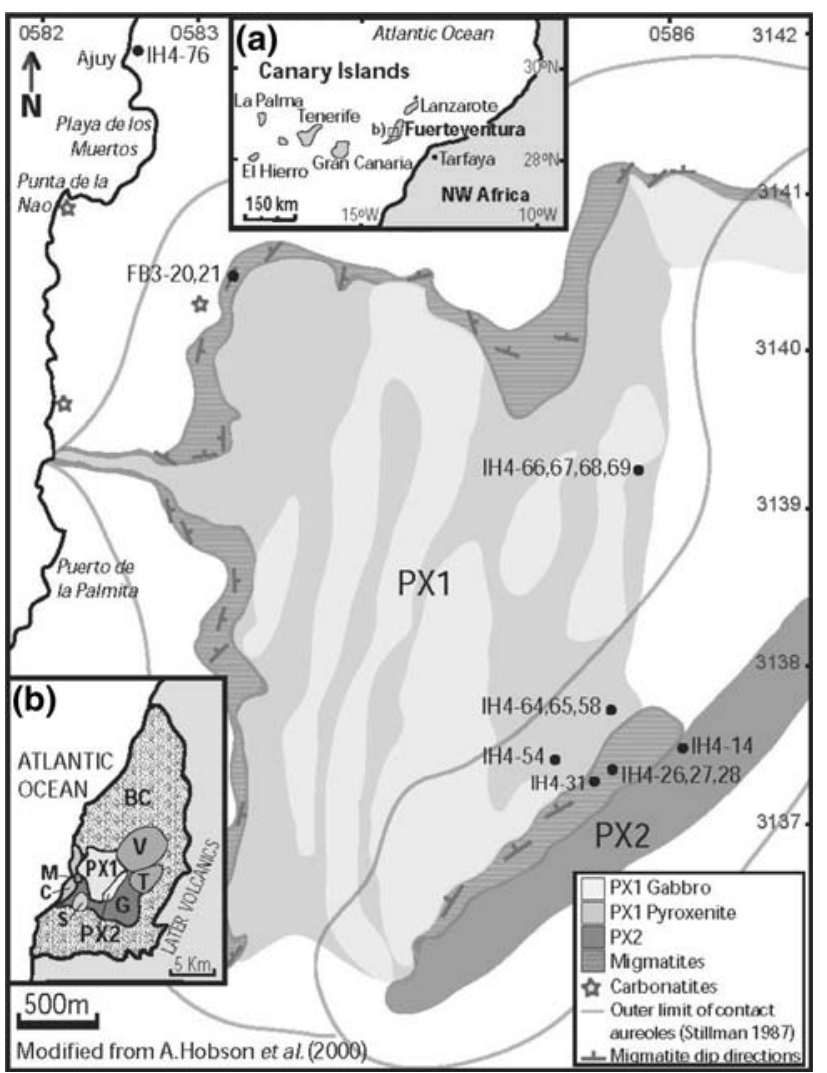

Fig. 1 Geological map of layered gabbro-pyroxenite intrusions PX1 and PX2 and their aureoles (modified from Hobson et al. 2000), showing sample localities and principal migmatite orientations. NNE to NE trending dykes are ubiquitous, but not represented on this map for clarity. Inset a Canary Island archipelago showing location of inset $b$ on Fuerteventura. $b$ Basal Complex of the Betancuria Massif (generalised outlines only) in reverse order of intrusion: $V$ Vega de Rio de Palmas, alkali gabbro-syenite ring complex (youngest); $T$ Toto, alkali gabbro-syenite ring complex; $M$ Tierra Mala 'Vega-type' syenite; PX2 latest gabbro-pyroxenite pluton; $P X 1$ late gabbropyroxenite pluton; $C$ carbonatite complex; $G$ early gabbro-pyroxenite (=Tierra mala s.1.); $B C$ bedded host rock to dyke swarm and plutons (oldest) (Le Bas et al. 1986)

Basic dykes traverse the whole Basal Complex, sometimes occupying more than $70 \%$ of the outcrops. Dykes post-PX1 but pre-PX2, with sub-vertical dips towards the NW, i.e., sub-parallel to PX2, are hydrothermally metamorphosed (static greenschist facies), and increasingly hornfelsed and ultimately migmatised, with proximity to the PX2 intrusion.

\section{Analytical techniques}

Whole-rock major and trace element analyses

Samples were crushed and subsequently reduced to a very fine powder by grinding in a tungsten carbide ring mill. Major and trace elements of whole-rock samples were analysed by X-ray fluorescence spectrometry and LA-ICPMS, at the University of Lausanne. Major elements ( $\mathrm{Si}, \mathrm{Ti}$, $\mathrm{Al}, \mathrm{Fe}, \mathrm{Mn}, \mathrm{Mg}, \mathrm{Ca}, \mathrm{Na}, \mathrm{K}, \mathrm{P}, \mathrm{Cr}$ and $\mathrm{Ni}$ ) were measured on fused lithium borate glass disks using a Philips PW2400 $\mathrm{X}$-ray fluorescence spectrometer. Trace elements were measured from pressed powder pellets on the same XRF spectrometer (Nb, Zr, Y, Sr, U, Rb, Th, Pb, Ga, Zn, Ni, Cr, $\mathrm{V}, \mathrm{Ce}, \mathrm{Ba}$ and $\mathrm{La}$ ), and by LA-ICP-MS on glass disks (Be, $\mathrm{Sc}, \mathrm{Ti}, \mathrm{V}, \mathrm{Cr}, \mathrm{Ni}, \mathrm{Cu}, \mathrm{Zn}, \mathrm{Y}, \mathrm{Zr}, \mathrm{Nb}, \mathrm{Cs}, \mathrm{La}, \mathrm{Ce}, \mathrm{Pr}, \mathrm{Nd}$, $\mathrm{Sm}, \mathrm{Eu}, \mathrm{Gd}, \mathrm{Tb}, \mathrm{Dy}, \mathrm{Ho}, \mathrm{Er}, \mathrm{Tm}, \mathrm{Yb}, \mathrm{Lu}, \mathrm{Hf}, \mathrm{Ta}, \mathrm{Pb}, \mathrm{Th}$ and $\mathrm{U})$. Tests were made to assess the amount of trace element contamination, such as $\mathrm{Ta}$ and $\mathrm{Nb}$, from the tungsten carbide mill. The samples analysed in this study are relatively rich in these elements, therefore contamination is considered negligible.

\section{Electron microprobe}

Microprobe analyses were made at the University of Lausanne with a CAMECA SX50. The accelerating voltage was $15 \mathrm{kV}$ for a beam current of 10-20 nA, depending on the sample analyzed. The beam was rastered over a surface of $10 \times 8$ microns for feldspars and $3 \times 2$ microns for hydrated minerals. Natural silicates were used as standards.

\section{LA-ICP-MS}

Laser ablation measurements were made with a $193 \mathrm{~nm}$ Lambda Physik $^{\odot}$ Excimer laser (Geolas 200M system) coupled to a Perkin-Elmer 6100 DRC ICP-MS, at the University of Lausanne, Switzerland. Laser settings were $27 \mathrm{kV}$ with a $10 \mathrm{~Hz}$ repetition rate, yielding a fluence of about $12 \mathrm{~J} / \mathrm{cm}^{2}$ on the ablation site. Helium was used as carrier gas $(1.1 \mathrm{l} / \mathrm{mn})$ and NIST612 glass was used as the external standard, and $\mathrm{Ca}$ and $\mathrm{Al}$ as internal standards (on the basis of electron microprobe measurements on the ablation pit site). BCR2 basaltic glass was regularly used as a monitor to check for reproducibility and accuracy of the system. Results were always within $\pm 10 \%$ of the values reported by Witt-Eickschen et al. (2003), while Rb, Cs, Y and especially $\mathrm{Cr}$ were sometimes off the $\pm 10 \%$ range of the USGS recommended values for BCR2. Wherever possible, several spots were analyzed for each phase to document the trace element variability within individual crystals and between crystals of the same thin section. Data reduction was done using LAMTRACE ${ }^{\circledR}$, a spreadsheet developed by S. E. Jackson (Macquarie University, Sydney).

Oxygen isotope analyses

Selected whole-rock powders and hand-picked mineral separates of clinopyroxene, plagioclase, biotite, oxides and amphiboles, were analysed. The samples were selected to 
cover the range of rock types found within each zone of the aureole, including samples from the hydrothermally metamorphosed zone, the PX2 intrusion itself and also a dyke unaffected by any metamorphism for comparison. The sample localities are shown in Fig. 1.

The oxygen isotope composition $\left({ }^{16} \mathrm{O},{ }^{18} \mathrm{O}\right)$ of the samples were measured at the University of Lausanne, using a method similar to that described by Sharp (1990) and Rumble and Hoering (1994) and which is described in more detail in Kasemann et al. (2001). Between 0.5 and $2.5 \mathrm{mg}$ of sample was loaded onto a small Pt-sample holder and pumped out to a vacuum of about $10^{-6}$ mbar. After prefluorination of the sample chamber overnight (or only $30 \mathrm{~min}$ for whole-rock powders or feldspars), the samples were heated with a $\mathrm{CO}_{2}$-laser in 50 mbar of pure $\mathrm{F}_{2}$. Excess $\mathrm{F}_{2}$ is separated from the $\mathrm{O}_{2}$ produced by conversion to $\mathrm{Cl}_{2}$ using $\mathrm{KCl}$ held at $150^{\circ} \mathrm{C}$. The extracted $\mathrm{O}_{2}$ is collected on a molecular sieve $(13 \times)$ and subsequently expanded into the inlet of a Finnigan MAT 253 isotope ratio mass spectrometer. Oxygen isotope compositions are given in the standard $\delta$-notation, expressed relative to VSMOW in permil $(\%)$. Replicate oxygen isotope analyses of the standards used [UWG-2 garnet $(n=2)$; Valley et al. 1995, and LS1 quartz $(n=2)$ an in-house standard normalised to NBS-28] for any one set of samples generally have an average precision of $\pm 0.2 \%$ for $\delta^{18} \mathrm{O}$. The accuracy of $\delta^{18} \mathrm{O}$ values is commonly better than $0.2 \%$ compared to accepted $\delta^{18} \mathrm{O}$ values for UWG-2 of $5.8 \%$.

\section{Field relationships and petrography}

PX2 is a vertically layered intrusion, located just west of Pájara on the SE fringe of the larger PX1 intrusion (Fig. 1). It is approximately $600-700 \mathrm{~m}$ wide and $3.5 \mathrm{~km}$ long (Hobson 2000), elongated NE-SW. It consists of alternating layers of alkali gabbro, wehrlite and pyroxenite, although it is largely dominated by pyroxenite with variable amounts of plagioclase and olivine. Layering is on a centimetric to metric scale, and is sub-parallel to the length of the intrusion, dipping $65-85^{\circ} \mathrm{NW}-\mathrm{NNW}$. PX1, the older alkali gabbro-pyroxenite, layered intrusion, forms the country rock to PX2 on its well-exposed, north-western side, but does not show abundant evidence of metamorphism of partial melting in the field.

The intensity of basanitic and clinopyroxene-phyric, ankaramitic dykes, in PX1, increases towards the PX2 contact (from 10 to $80 \%$ ). It is the nature of these dykes, in the vicinity of PX2, that clearly shows the extreme effects of thermal metamorphism, to the point of anatexis. With increasing proximity to the PX2 intrusion an evolution from unaltered ankaramitic to hydrothermally altered (greenschist facies) dykes is observed outside the aureole, and from hornfelsed to migmatised dykes within the aureole.

Migmatised dykes

Dykes found within the first $250 \mathrm{~m}$ of the PX2 intrusion (samples IH4-26, 27 and 31; Fig. 1) all resemble 'migmatites' (Fig. 2). They are characterised by a dense network of closely spaced, millimetre-wide, leucocratic segregations (Fig. 2a), but differ from migmatites produced in regional metamorphic terrains by the lack of deformation textures in their melanosome and leucosome. Predominant leucosome orientations are sub-parallel to PX2 and their respective dyke margins, although conjugate leucosomes are also observed (Fig. 2a).

Leucosomes, thought to be representative of a 'melt', are composed of $70 \%$ andesine plagioclase $\left(\mathrm{An}_{32-36}\right), 24 \%$ diopside, $4 \%$ oxides and $2 \%$ biotite. No post-solidus deformation appears to have taken place, as plagioclase and diopside form comb-like, igneous textures, elongated perpendicular to leucosome walls (Fig. 2c). The finer grained melanosome, is a fairly homogeneous lithology with a granoblastic, polygonal texture, and well-developed triple junctions (Fig. 3c and inset). Mineralogically it is similar to the leucosome, but modes are different due to the lower abundance of plagioclase. We interpret this melanosome as a completely recrystallised, more or less restitic mineral assemblage from which melt segregated.

Dyke centres preserve large $(2-10 \mathrm{~mm})$, relict clinopyroxene phenocrysts, around which leucosomes are distributed (Fig. 2b). They appear to be the only igneous remnants that escaped complete recrystallisation. They do however contain abundant ilmenite exsolution lamellae (Fig. 3f), a feature possibly related to thermal metamorphic processes. Neocrystallised diopside appears to have grown epitaxially along the rim of such relict phenocrysts (Fig. 3f).

No significant differences are noted between leucosome and melanosome major element mineral compositions, however, relict clinopyroxene phenocrysts have slightly higher $\mathrm{Ti}$ and $\mathrm{Al}$ contents than the small neocrystallised diopside from the matrix (eTable 1a; Holloway and Bussy 2007).

\section{Hornfelsed dykes}

Beyond $250 \mathrm{~m}$ from the PX2 intrusion no more evidence for partial melting is found. Matrix textures largely resemble those found in the migmatite melanosomes, but with a smaller grain-size (Fig. 3b). They consist of small, recrystallised diopside, oligoclase-andesine plagioclase $\left(\mathrm{An}_{23-46}\right.$; a slightly larger compositional range than plagioclase in the migmatised dykes, probably due to a lower 

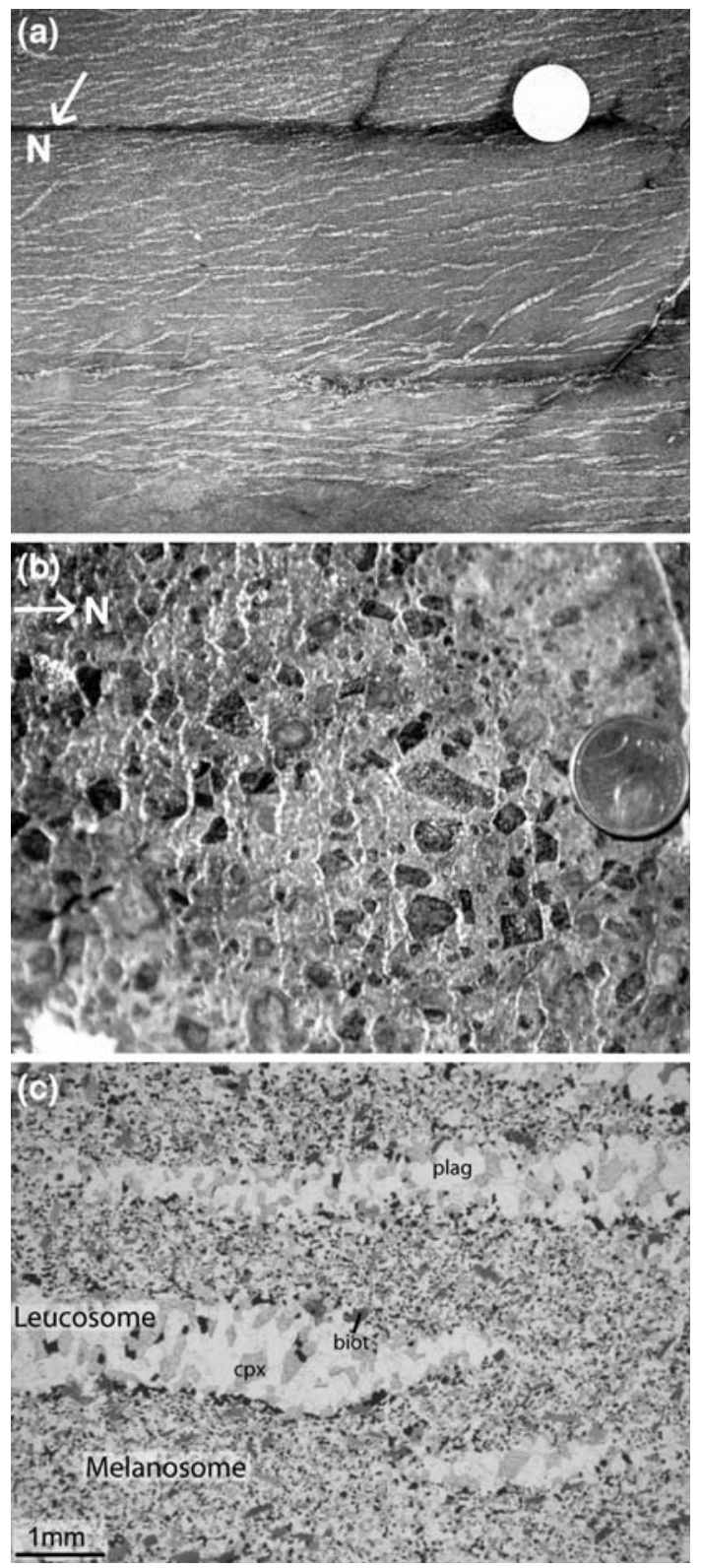

Fig. 2 Field photographs of a PX2 aureole migmatite (coin for scale, diameter $=21 \mathrm{~mm}$ ), and $\mathbf{b}$ central phyric part of migmatised dyke from PX1 aureole (coin for scale, diameter $=19 \mathrm{~mm}$ ). c Photomicrograph of a migmatite showing well-developed leucosomes and melanosomes. Minerals include plagioclase (plag), diopside (cpx), biotite (biot) and oxides (ilmenite and magnetite). Non-deformed, igneous textures-with crystals aligned perpendicular to vein walls-are preserved in these leucosomes

degree of equilibration), fairly abundant biotite (that forms pseudomorphs or haloes around relict phenocrysts), ilmenite, magnetite, kaersutite, and larger, relict minerals. Few elongate, labradorite plagioclases, resembling igneous remnants are preserved. In these hornfelsed dykes, the large, relict clinopyroxene phenocrysts, only contain ilmenite exsolution lamellae on outer parts of crystals (Fig. 3e, eTable 1).
Such characteristics are found up to approximately $700 \mathrm{~m}$ from PX2, defining the hornfels zone (samples IH454, 64, 65; Fig. 1) and delimiting the metamorphic contact aureole.

Hydrothermally metamorphosed (Greenschist facies) dykes

Outside the contact aureole, beyond $700 \mathrm{~m}$ from PX2 but still within the PX1 intrusion, the intensity of dykes diminishes rapidly, and they appear increasingly hydrothermally altered to the greenschist facies (samples IH4$66,67,68$; Fig. 1). Texturally there is no longer any sign of contact metamorphic recrystallisation, as igneous intersertal/intergranular, seriate textures are preserved (Fig. 3a). Nevertheless, these dykes appear to have undergone a pervasive, hydrothermal event, as they are dominated by secondary hydrous minerals, e.g., edenite. They also contain albitic plagioclase $\left(\mathrm{An}_{0-48}\right)$, often sericitised or altered to zeolites, kaersutite, magnetite, ilmenite, sphene and rare scapolite and calcite. The large, relict igneous phenocrysts of clinopyroxene, that are unaltered by any metamorphism (Fig. 3d), do not contain any ilmenite exsolution lamellae, but sometimes have Ti-rich patches or rims. However, some are partially or entirely replaced by edenite (Fig. 3d, inset). Numerous phenocryst pseudomorphs (after clinopyroxene or olivine) contain a mixture of fibrous, hydrous, green to white minerals such as edenite, tremolite and actinolite.

\section{Ankaramitic dykes}

An ankaramitic dyke from outside the PX2 and PX1 contact aureoles, that does not appear to have been influenced by the hydrous metamorphic event (sample IH4-76; Fig. 1, top left near Ajuy), was sampled as representative of an unaltered igneous rock. It is dominated by phenocrysts of titanaugite (eTable 1a), with few olivines. The matrix consists of microcrysts of titanaugite, magnetite and olivine surrounded by small but often poikilitic plagioclase enveloping even smaller crystals of the aforementioned minerals, including fine apatite needles.

\section{Geochemistry}

The PX2 pyroxenite and all the lithologies in and around its aureole, are mafic to ultramafic, and diopside, olivine, and nepheline normative. They are all metaluminous, alkaline, and relatively $\mathrm{TiO}_{2}, \mathrm{FeO}_{\text {total }}$ and $\mathrm{MgO}$ rich (3-5 wt\%, 13 $20 \mathrm{wt} \%$ and $5-10 \mathrm{wt} \%$, respectively). All dykes are basanitic to basaltic in composition, and generally have comparable whole-rock, major-element compositions. 

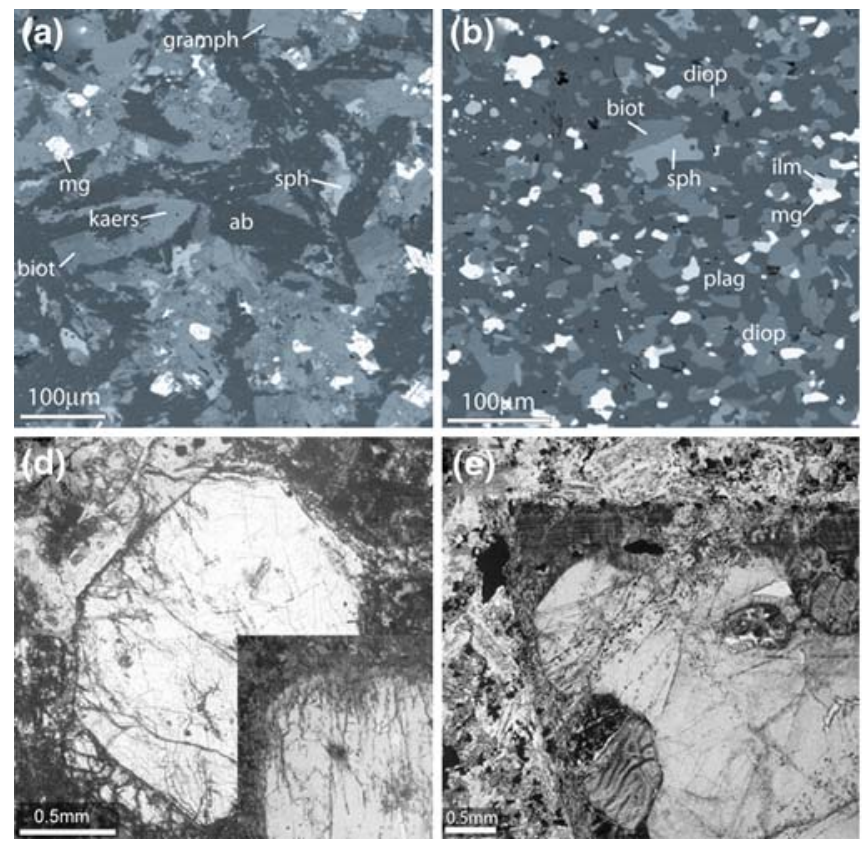

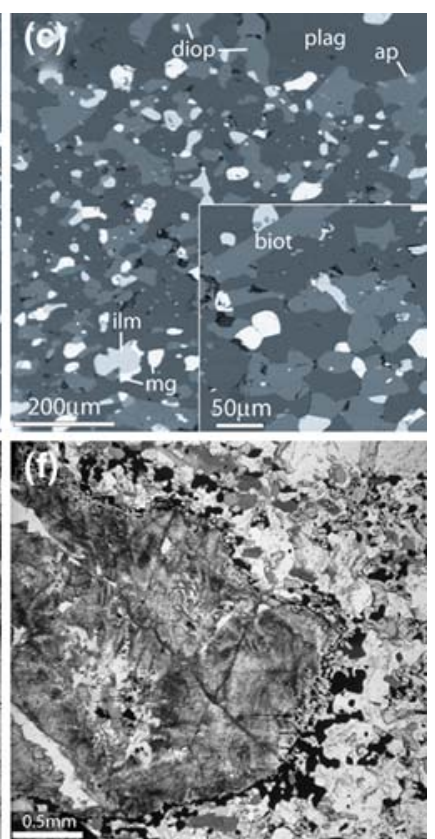

Fig. 3 Back-scattered electron (BSE) images of dyke matrices a greenschist facies b hornfels c migmatite, showing increasing recrystallisation towards the intrusion (migmatite zone). Note: preservation of igneous intergranular-intersertal textures in the greenschist facies dyke, a noticeably smaller grain-size in the hornfels with similar equigranular textures but a larger grain-size than in the migmatite zone. Photomicrographs of clinopyroxene phenocrysts from $\mathbf{d}$ greenschist facies e hornfels and $\mathbf{f}$ migmatised dyke centres, showing increasing ilmenite exsolution towards the intrusion (migmatite zone). $a b$ albite, $s p h$ sphene, biot biotite, kaers kaersutite, $m g$ magnetite, gr amph green amphibole, diop diopside, ilm ilmenite, plag plagioclase, ap apatite
Only the greenschist dykes outside the aureole differ in their higher volatile contents (up to $3 \mathrm{wt} \%$ ). In terms of trace elements all the dykes retain their OIB signatures with a strong enrichment in the most incompatible elements of up to 200 times the primitive mantle. Smaller scale variations of dyke compositions within and outside the aureole are not pronounced and do not follow any trend towards/away from the intrusion (Holloway and Bussy 2007).

\section{Oxygen isotope compositions of rocks and minerals}

The similarity of the whole-rock geochemistry of dykes from the migmatite, hornfels, and greenschist zone, allow oxygen isotope compositions to be compared directly without having to correct for fractionations caused by original magmatic differences, or transport of material into or out of the dykes during metamorphism.

Low pressure anatexis of basic dykes in the contact metamorphic aureole of the PX2 pyroxenitic intrusion, was attained by the successive intrusion of numerous magma batches, producing a continuously high heat flow, along with the inferred presence of fluids. In order to gain insight into the nature and origin of these fluids, oxygen isotope compositions of whole-rock powders and mineral separates of clinopyroxene, feldspar, biotite, amphibole, and oxides from in and around the PX2 aureole were measured. Results (given in eTable 2) provide unequivocal evidence for interaction of migmatised, hornfelsed, and greenschist facies dykes just outside the aureole, with meteoric fluids.

\section{Whole-rocks}

All dykes in and around the PX2 aureole, in the migmatite, hornfels and greenschist zone, have low or even negative whole-rock $\delta^{18} \mathrm{O}$ values $(+0.2$ to $-3.4 \%$ oo, decreasing towards the intrusion (Fig. 4), with lowest values in the anatectic zone. Furthermore, the aphyric dykes or dyke edges have lower values than the phyric central parts of dykes (Fig. 4). The PX1 gabbro, forming the country rock to the PX2 intrusion, also has fairly low $\delta^{18} \mathrm{O}$ values $(+1.0$ to $+2.8 \%$ o decreasing within the aureole towards the intrusion, although this trend is much less pronounced than that shown by the dykes. The PX2 intrusion itself has a $\delta^{18} \mathrm{O}$ value of $+4.2 \%$, approaching a value more typical for basic, mantle-derived melts. Migmatised dykes from the PX1 aureole and an ankaramitic dyke from beyond both aureoles, unaffected by any meteoric-hydrothermal events, have the highest $\delta^{18} \mathrm{O}$ values $(+5.1$ to $+5.6 \%$ o $)$, likely representing original magmatic values. 


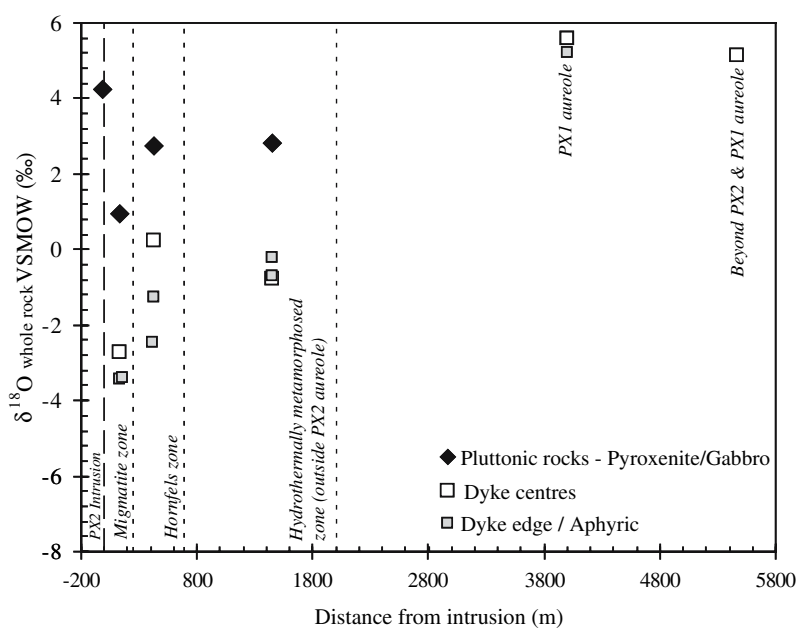

Fig. 4 Whole-rock $\delta^{18} \mathrm{O}$ values for representative samples from the PX2 intrusion and its contact aureole, plotted as a function of distance from the intrusion

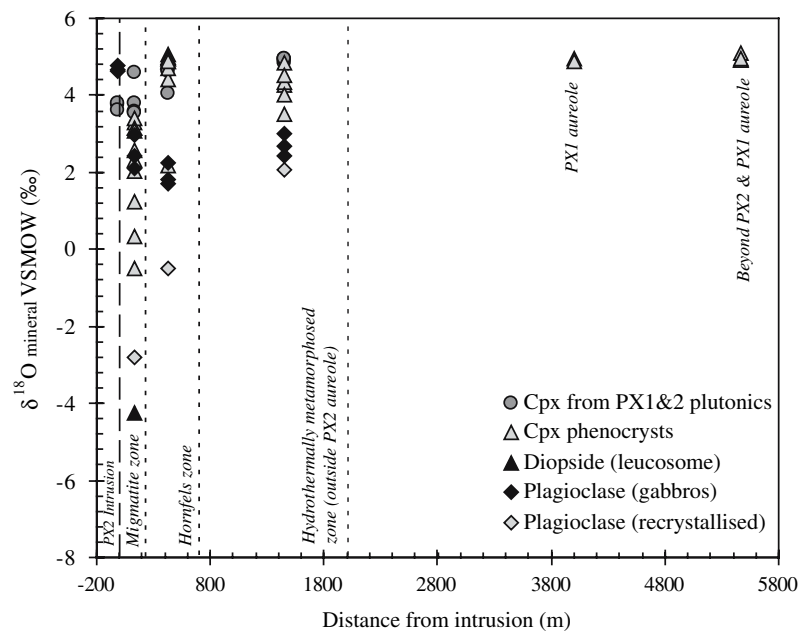

Fig. $5 \delta^{18} \mathrm{O}$ values of clinopyroxene and plagioclase; (a) from plutonic rocks (PX1 host gabbro and PX2 pyroxenite), (b) neocrystallised in dykes; and $(c)$ relict clinopyroxene phenocrysts. Plotted as a function of distance from the PX2 intrusion

\section{Mineral separates}

PX2 pyroxenite mineral separates only deviate slightly from the whole-rock composition, clinopyroxene with lower (about $+3.7 \%$ ) and plagioclase with higher (about $+4.7 \%$ ) values (Fig. 5). The large igneous clinopyroxenes from the PX1 gabbros and relict phenocrysts in the dykes from within the aureole, that escaped recrystallisation during contact metamorphism, have higher $\delta^{18} \mathrm{O}$ values than their respective whole-rock compositions (compare Figs. 4, 5). However, there is a large heterogeneity between and within single relict clinopyroxene phenocrysts in the aureole (see eTable 2), with the lowest $\delta^{18} \mathrm{O}$ values

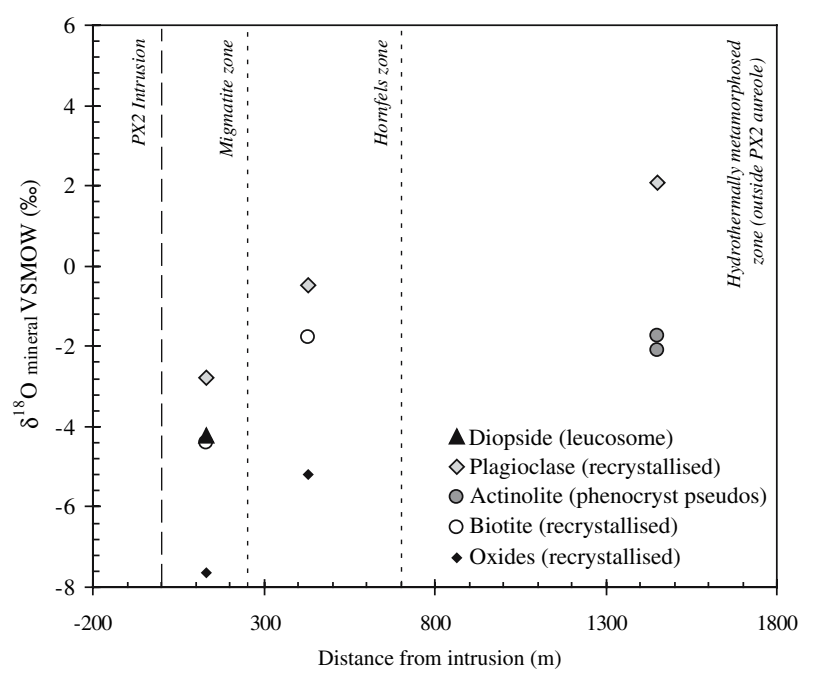

Fig. $6 \delta^{18} \mathrm{O}$ values of neo- or re-crystallised minerals; diopside, plagioclase, actinolite, biotite and oxides, found in migmatised, hornfelsed and greenschist dykes, plotted as a function of distance from the PX2 intrusion

measured from the migmatite zone $(-0.5 \%)$ and highest from the hornfels zone $(+5.1 \%)$.

Plagioclase from the PX1 gabbro has lower $\delta^{18} \mathrm{O}$ values $(+1.7$ to $+3 \%$ o $)$ than the PX2-pyroxenite plagioclase (about $+4.7 \%$ ), but not as low as the recrystallised plagioclase from the dykes of the aureole $(-2.8$ to $-0.5 \%$; Fig. 5), that decreases with proximity to the intrusion.

All neo- and recrystallised minerals from dykes within and just outside the aureole, in the hydrothermally metamorphosed zone, have low $\delta^{18} \mathrm{O}$ values, with a pronounced decrease towards the intrusion (Fig. 6). Plagioclase, diopside, biotite and oxides (magnetite and ilmenite) from the migmatites, yield consistent $\delta^{18} \mathrm{O}$ values of $-2.8,-4.2,-4.4$ and $-7.6 \%$, respectively, in terms of their relative order of decreasing content of ${ }^{18} \mathrm{O}$. Similar values were obtained for minerals separated from the leucosomes and melanosomes. However, in the hornfelsed dykes, plagioclase, biotite and oxides yield consistently higher values of $-0.5,-1.8$ and $5.2 \%$, respectively (diopside was unfortunately too finegrained for separation).

In summary, $\delta^{18} \mathrm{O}$ values of dykes, in and around the PX2 aureole, that pre-date PX2 but cut PX1, are lower than those of normal, mantle-derived mafic rocks, and decrease towards the PX2 intrusion. Negative $\delta^{18} \mathrm{O}$ values can only be obtained by interaction with meteoric fluids and/or melting of material that has previously been depleted in ${ }^{18} \mathrm{O}$ through exchange with meteoric water. Higher or even normal mantle-derived magmatic values for some relict clinopyroxene phenocrysts supports an exchange with low $\delta^{18} \mathrm{O}$ meteoric water during emplacement though, with minerals that are recrystallising being open to this exchange. Therefore, any decrease in $\delta^{18} \mathrm{O}$ observed in relict 
phenocrysts may be related to diffusive exchange or exchange along small zones of alteration/recrystallisation within the grains but not visible in thin section. However, smaller, recrystallised minerals from dykes within the aureole and outside the aureole in the hydrothermal zone, all have negative $\delta^{18} \mathrm{O}$ values, appearing to have recrystallised in the presence of and in equilibrium with a relatively ${ }^{18} \mathrm{O}$-poor meteoric fluid phase.

Diffusion distances were calculated for clinopyroxene (diopside), using the following equations: $X=\sqrt{ } D t$ and $D=D_{0} \mathrm{e}^{\left(-E_{\mathrm{a}} / R T\right)} \quad$ (after Valley 2001), where the preexponential diffusion coefficient $D_{\mathrm{o}}=1.5 \times 10^{-6} \mathrm{~cm}^{2} / \mathrm{s}$, the activation energy $E_{\mathrm{a}}=226 \mathrm{~kJ} / \mathrm{mol}$ (Farver 1989), and the gas constant, $R=8.3143 \mathrm{~J} /{ }^{\circ} \mathrm{kmol}$. An estimation of the maximum time $(t)$, during which the temperatures remained just below melting temperatures $\left(T=1,000^{\circ} \mathrm{C}\right.$ or 1,323 K, Holloway and Bussy 2007; Koepke et al. 2003) but above closure temperatures for diffusion, was made in order to calculate the maximum diffusion distance $(X)$ possible for the clinopyroxene phenocrysts. In $1,000,000$ years (a cautious overestimate) the diffusion distance would not have exceeded $2 \times 10^{-3} \mu \mathrm{m}$. Oxygen isotope exchange by diffusion does not, therefore, appear to be a plausible mechanism for the depletion of ${ }^{18} \mathrm{O}$ in the 2-10 mm clinopyroxene phenocrysts of the PX2 aureole.

$\delta-\delta$ diagrams (Fig. 7) may illustrate whether rocks have undergone hydrothermal alteration events after first formation of the minerals or whether they have reached and preserved isotopic equilibrium at the time of crystallisation. Plagioclase, being more susceptible to low temperature sub-solidus alteration (e.g., Criss and Taylor 1986; Criss et al. 1987), may exchange with water down to lower closure temperatures compared to pyroxene, and hence have lower $\delta^{18} \mathrm{O}$ values if exchanging with meteoric water (e.g., Taylor and Forester 1979). Hence, high $\Delta^{18} \mathrm{O}$ px plag values, such as all points lying below the equilibrium isotopic fractionation lines on Fig. 7, represent mineralpairs out of isotopic equilibrium, where the plagioclase was open to exchange with meteoric fluids. The disequilibrium between mineral pairs in the PX1 gabbros (Mig, Hornf and Green Gabbros in Fig. 7) and the greenschist facies dyke (Green dyke) thus provide evidence of sub-solidus hydrothermal alteration. However, the accentuated fractionations observed between the migmatite and hornfels relict, clinopyroxene phenocrysts and their matrix plagioclase (Mig and Hornf dyke, Fig. 7) is probably related to increased exchange between the plagioclase and the fluid during and after recrystallisation.

Pyroxene and plagioclase from the PX2 pyroxenite and the recrystallised migmatite matrix (leucosome and melanosome) (PX2 and Mig leuco in Fig. 7) appear to have crystallised under equilibrium magmatic conditions as they have small fractionations that also correspond to approximate

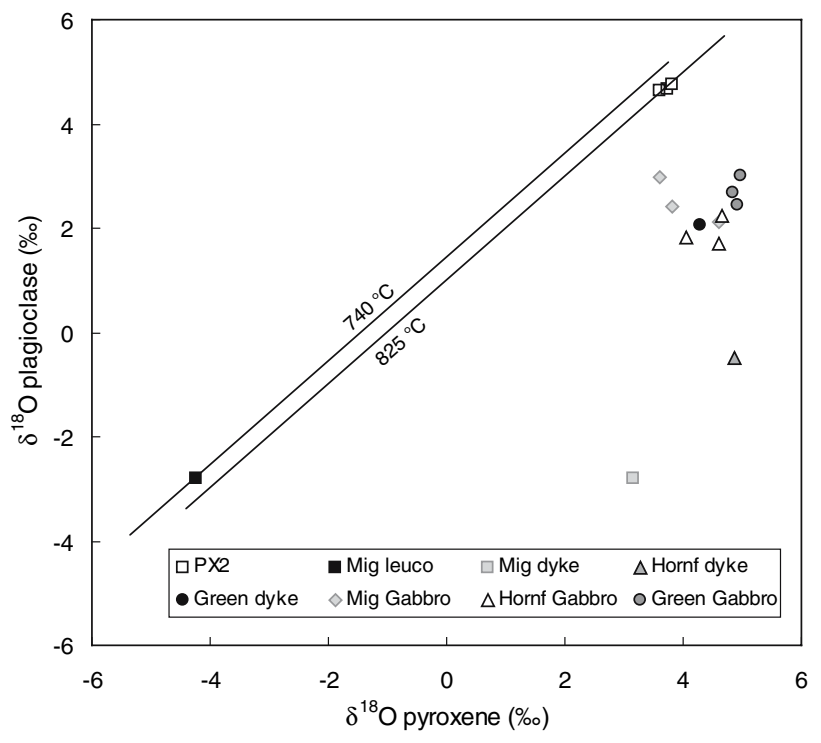

Fig. 7 A plot of $\delta^{18} \mathrm{O}$ plagioclase versus $\delta^{18} \mathrm{O}$ pyroxene for dykes and plutonics in the PX2 aureole, including the PX2 intrusion itself. Equilibrium isotopic fractionation lines are shown: (a) $740^{\circ} \mathrm{C}$; a fractionation of +1.44 , for a plagioclase composition of $\mathrm{An}_{32}$, and (b) $825^{\circ} \mathrm{C}$; a fractionation $+0.93-0.97$, for an average plagioclase compositions of $\mathrm{An}_{63}$. Mig leuco minerals from migmatite leucosome (IH4-27); Mig dyke relict cpx phenocrysts from migmatite and matrix (leucosome/melanosome) plagioclase (IH4-26), Hornf dyke relict cpx phenocrysts from hornfelsed dyke and matrix plagioclase (IH4-65), Green dyke relict cpx phenocrysts from greenschist facies dyke and matrix plagioclase (IH4-68), Mig Gabbro gabbro from migmatised zone (IH4-28), Hornf Gabbro gabbro from hornfelsed zone (IH4-58), Green Gabbro gabbro from greenschist facies zone (IH4-69)

closure temperatures for pyroxene in intrusive gabbroic rocks. Nevertheless, the migmatite is obviously in equilibrium with a low $\delta^{18} \mathrm{O}$ meteoric fluid, whereas PX2 appears to have only slightly lower than normal magmatic values. Temperatures implied by such fractionations (calculated using the equation: $\delta^{18}$ Oplag $-\delta^{18} \mathrm{Ocpx}=A \times 10^{6} / T^{2}$, where $T$ is temperature, and $A$ coefficients for plagioclaseclinopyroxene fractionation factors (migmatite; $\mathrm{An}_{32}-$ $\mathrm{Di}=1.47$ : PX2 pyroxenite; $\mathrm{An}_{63}-\mathrm{Di}=1.15$ ) taken from Table 5 in Chacko et al. 2001) are in the order of 740 and $825^{\circ} \mathrm{C}$, for the migmatite and PX2 pyroxenite, respectively. These temperatures may well represent cooling temperatures and/or closure temperatures in a more or less binary pyroxene-plagioclase system, where the plagioclase closes to isotopic exchange once the pyroxene has closed. The different temperatures recorded may be due to the smaller grain-size of the migmatites compared to the pyroxenite.

\section{Discussion}

Estimated temperatures necessary for the partial melting of the basic igneous dykes in the PX2 contact metamorphic 
aureole at pressures of $1-2 \mathrm{~kb}$ are in the order of $1,000^{\circ} \mathrm{C}$, with the assumption that fluids were present to decrease their solidus temperatures. Experiments by Koepke et al. (2003, Fig. 3b), on Tierra Mala ferrogabbros (from the PX1 country-rock), show that the proportion of melt produced is not only sensitive to temperature and pressure, but is also highly dependant on the bulk water content: at $2 \mathrm{~kb}$ and $1,000^{\circ} \mathrm{C}, 1 \mathrm{wt} \%$ water content produced $10 \%$ melt, whereas $3 \mathrm{wt} \%$ water content produced $35 \%$ melt. The unaltered ankaramitic dyke (IH4-76, Holloway and Bussy 2007) far away from the PX2 aureole, contains a mere $0.7 \mathrm{wt} \% \mathrm{H}_{2} \mathrm{O}$, not nearly enough to produce the $25 \%$ melt thought to be represented by leucosomes in the migmatised dykes close to the intrusion. However, the hydrothermally metamorphosed basanitic dykes found just beyond the aureole, the hypothesised migmatite protoliths, contain up to $3 \mathrm{wt} \% \mathrm{H}_{2} \mathrm{O}$, sufficient to account for the melt proportions at attainable temperatures.

Circulation of high altitude meteoric water through a volcanic edifice at temperatures of $300-500^{\circ} \mathrm{C}$, i.e., static greenschist facies conditions, may well have caused the hydrous recrystallisation of all dykes in the vicinity of the edifice, thereby decreasing their $\delta^{18} \mathrm{O}$ values. Fluid convection driven by an intrusion would have enhanced the circulation of meteoric fluids and also oxygen exchange (Valley 1986). Low $\delta^{18} \mathrm{O}$ values of all rocks showing signs of subsolidus hydrothermal alteration, such as the greenschist facies dykes found just outside the PX2 thermal aureole, can therefore be attributed to meteoric-hydrothermal fluid circulation. Many studies on oxygen isotope variations in ophiolites (e.g., Gregory and Taylor 1981; Muehlenbachs 1986; Eiler 2001; Stakes and Taylor 2003), focussing on low and high temperature hydrothermal alteration processes, have described changes in whole-rock $\delta^{18} \mathrm{O}$ values caused by seawater interaction with oceanic crust. However, the changes noted do not result in depletions in ${ }^{18} \mathrm{O}$ in the order of those observed in the present system.

The systematic $\delta^{18} \mathrm{O}$ decrease in dykes of the PX2 contact metamorphic aureole, towards higher metamorphic grades, is a trend observed in many other meteorichydrothermal systems around plutonic complexes. Such systems have been well reviewed by Criss and Taylor (1986, Table 1). One example of a gabbroic intrusion with ${ }^{18} \mathrm{O}$ depleted volcanic wall rocks is the Tertiary Cuillin and Red Hills intrusive complexes, Isle of Skye, Scotland: $\delta^{18} \mathrm{O}$ values of the contact metamorphosed basaltic country rocks systematically decrease towards the plutonic complex, down to $-7.1 \%$ in the highest grade olivine zone (Forester and Taylor 1977). Explanations proposed for this radial inward depletion in ${ }^{18} \mathrm{O}$, i.e., the 'bullseye' pattern (Criss and Taylor 1986), essentially involve increasing temperatures toward the intrusive centres: Higher temper- atures promote more rapid and extensive isotopic exchange causing the rocks to have $\delta^{18} \mathrm{O}$ values that approach those of the meteoric $\mathrm{H}_{2} \mathrm{O}$ (Forester and Taylor 1977). In addition, the fractionation factors between minerals and fluid decrease with increasing temperature. Ferry et al. (1987) also suggested that most of the hydrothermal alteration in the high-grade zone occurred at temperatures $>1,000^{\circ} \mathrm{C}$ while heated by the intrusions.

Large xenoliths of metabasalt found in the layered gabbros of the Kap Edvard Holm Intrusive Complex (East Greenland), closely resemble the hornfelsed dykes in the PX2 aureole, in terms of mineralogy, their fine-grained equigranular granoblastic textures, and their substantial depletion in ${ }^{18} \mathrm{O}$ compared to fresh basalts (Brandriss et al. 1996). Oxygen isotope fractionation between coexisting plagioclase and pyroxene in the xenoliths reflects equilibration with low $\delta^{18} \mathrm{O}$ fluids at temperatures of approximately $1,000^{\circ} \mathrm{C}$ (Brandriss et al. 1992). Interpretations involve subsolidus meteoric-hydrothermal alteration of basaltic country rocks prior to stoping (Brandriss et al. 1995), followed by reheating to magmatic temperatures on assimilation, causing dehydration, partial melting and hornfelsic recrystallisation at temperatures $>1,050^{\circ} \mathrm{C}$ (Brandriss et al. 1996). This would have restored a pyroxene-plagioclase equilibrium with low $\delta^{18} \mathrm{O}$ values. A similar scenario could be envisaged for the dykes in the PX2 aureole (without stoping), whereby low temperature meteoric-hydrothermal alteration occurred prior to or during the initial stages of PX2 emplacement. Intrusion of the PX2 magmas heated the wall rocks sufficiently to cause partial to complete recrystallisation further away and partial melting closer to the intrusive centre. Changes in $\delta^{18} \mathrm{O}$ values are then closely coupled to the extent of recrystallisation and extent of fluid-mineral exchange during the recrystallisation.

Decreasing $\delta^{18} \mathrm{O}$ values towards the intrusion could also be partially attributed to the devolatilisation of the hydrothermally altered rocks with increasing temperature during contact metamorphism (Valley 1986): the fractionation factor of ${ }^{18} \mathrm{O} /{ }^{16} \mathrm{O}$ between $\mathrm{H}_{2} \mathrm{O}$ and melt or minerals is larger than unity at high temperatures (above $600^{\circ} \mathrm{C}$, e.g., Chacko et al. 2001) i.e., ${ }^{18} \mathrm{O}$ preferentially partitions into the aqueous fluid and the $\delta^{18} \mathrm{O}$ of melt and minerals after dehydration will be lower. Increasing temperatures with proximity to the intrusion, causing increasing dehydration of hydrothermally altered dykes, may thus also cause a decrease in $\delta^{18} \mathrm{O}$ values. However, the magnitude of this isotopic effect is controlled by the amount of water expelled (limited to $2-3 \mathrm{wt} \%$ for the greenschist dykes), and can not exceed $1 \%$ (e.g., Baumgartner and Valley 2001), i.e., a process much less effective in lowering the $\delta^{18} \mathrm{O}$ values than infiltration of low $\delta^{18} \mathrm{O}$ fluids. 
Increasing fluid/rock ratios towards the PX2 intrusion could also account for the observed trends in $\delta^{18} \mathrm{O}$ values. Increasing dyke intensity towards $\mathrm{PX} 2$, probably reflects a higher fracture intensity towards the intrusion, along which fluid-flow may have focussed, preferentially altering the finer-grained dykes. Such channelised fluid flow would have created higher bulk system fluid/rock ratios towards the PX2 intrusion as dyke intensity is greater in proximity to the intrusion. $\delta^{18} \mathrm{O}$ whole-rock values would thus decrease heterogeneously towards the intrusion, with larger depletions in the dykes than their gabbroic hosts, as is observed in this study. Increasing fluid/rock ratios in addition to an increase in temperature can also propagate a radially inward fluid flow (e.g., Taylor 1971) of a more pervasive nature, thereby possibly increasing water/rock ratios towards the margin of the intrusion (in a relatively closed system). However, in order to have decreasing $\delta^{18} \mathrm{O}$ values with approach to the intrusive contact, it is imperative that the fluid has not been extensively buffered by the wall rocks with approach to the contact as this would only raise the ${ }^{18} \mathrm{O}$ content of the fluid during increasing exchange. Hence, a fluid source close to the intrusive system and/or an increasing channel density for fluid transport are required (e.g., Conrad et al. 1997). Fluid flow paths would have been largely deflected around the impermeable PX2 magma sheets while hot, resulting in the preservation of relatively high $\delta^{18} \mathrm{O}$ values compared to wall rocks. Slight depletions compared to normal mantle values may be due to partial exchange with meteoric fluids upon cooling of the intrusion. Nevertheless, a lack of evidence for late, sub-solidus hydrothermal alteration in the high-grade rocks near the PX2 intrusive contact, and in the PX2 intrusion itself, preclude the possibility of a post-PX2 hydrothermal event.

\section{Conclusions}

The low $\delta^{18} \mathrm{O}$ values of basic dykes in and around the PX2 contact metamorphic aureole imply that the fluids necessary for their low-pressure anatexis were of meteoric origin. Exchange of the rocks with meteoric-hydrothermal fluids may have started during initial stages or possibly even before the intrusion of PX2. The intrusion of PX2 may have created fluid convection cells, thus enhancing fluid infiltration and exchange with the ${ }^{18} \mathrm{O}$ depleted fluids during recrystallisation of the country rock.

Decreasing $\delta^{18} \mathrm{O}$ values towards the PX2 intrusion could be attributed to increasing fluid/rock ratios and/or temperature. Increasing dyke intensity towards PX2 supports emplacement of PX2 into a structurally weakened and fractured zone that also offers an increase in possible fluid pathways and hence in overall fluid/rock ratio with approach to the intrusion. In parallel, increasing tempera- ture towards PX2 facilitates exchange between advecting meteoric fluids and recrystallising minerals, thus similarly leading to a decrease in $\delta^{18} \mathrm{O}$ values towards the intrusion.

Acknowledgments We would like to thank Lukas Baumgartner for helpful discussions, and reviewers (Luigi Dalai and an anonymous reviewer) for their useful comments. Many thanks also to Jean-Claude Lavanchy (CAM, University of Lausanne) for the whole-rock XRF analyses, Sébastien Pilet and Alexey Ulianov for their help on the LAICP-MS, Benita Putlitz for her help with the $\mathrm{CO}_{2}$ laser-line in the stable isotope laboratory, and the Cabildo Insular de Fuerteventura for their permission to sample in the studied area. This research was supported by the Swiss National Science Foundation (project no. 200021-100493 and 200020-108033).

\section{References}

Balogh K, Ahijado A, Casillas R, Fernández C (1999) Contributions to the chronology of the Basal Complex of Fuerteventura, Canary Islands. J Volcanol Geoth Res 90:81-101

Banda E, Danobeitia JJ, Surinach E, Ansorge J (1981) Features of crustal structure under the Canary Islands. Earth Planet Sci Lett 55(1):11-24

Baumgartner LP, Valley JW (2001) Stable isotope transport and contact metamorphic fluid flow. In: Valley JW, Cole DR (eds) Stable isotope geochemistry. Rev Mineral Geochem 43:415-467

Bédard JH (1991) Cumulate recycling and crustal evolution in the Bay of Islands ophiolite. J Geol 99:225-249

Brandriss ME, Bird DK, O'Neil JR (1992) Dependence of hydrothermal alteration on rock texture and microporosity in mafic crystalline rocks. In: Kharaka YK, Maest AS (eds) Proceedings of the 7th international symposium on water-rock interaction, vol 2. Moderate and high temperature environments, pp 14771480. International Association of Geochemistry and Cosmochemistry and Alberta Research Council, Sub-Group on WaterRock Interaction, Edmonton, AB, International

Brandriss ME, Nevle RJ, Bird DK, O'Neill JR (1995) Imprint of meteoric water on the stable isotope compositions of igneous and secondary minerals, Kap Edvard Holm Complex, East Greenland. Contrib Mineral Petrol 121:74-86

Brandriss ME, Bird DK, O’Neill JR, Cullers RL (1996) Dehydration, partial melting, and assimilation of metabasaltic xenoliths in gabbros of the Kap Edvard Holm Complex, East Greenland. Am J Sci 296:333-393

Cantagrel JM, Fúster JM, Pin C, Renaud U, Ibarrola E (1993) Age Miocène inférieur des carbonatites de Fuerteventura (23 Ma: U$\mathrm{Pb}$ zircon) et le magmatisme précoce d'une île océanique (îles Canaries). C R Acad Sci II 316:1147-1153

Chacko T, Cole DR, Horita J (2001) Equilibrium oxygen, hydrogen and carbon isotope fractionation factors applicable to geologic systems. In: Valley JW, Cole DR (eds) Stable isotope geochemistry. Rev Mineral Geochem 43:1-81

Coello J, Cantagrel JM, Hernán F, Fúster JM, Ibarrola E, Ancochea E, Casquet C, Jamond C, Díaz de Téran JR, Cendrero A (1992) Evolution of the eastern volcanic ridge of the Canary Islands based on new K-Ar data. J Volcanol Geoth Res 53(1-4):251-274

Conrad ME, Thomas DM, Flexser S, Vennemann TW (1997) Fluid flow and water-rock interaction in the East Rift Zone of Kilauea Volcano, Hawaii. J Geophys Res 102(B7):15021-15037

Criss RE, Taylor HP Jr (1986) Meteoric-hydrothermal systems. In: Valley JW, Taylor HP, O'Neil JR (eds) Stable isotopes in high temperature geological processes. Rev Mineral Min Soc Am $16: 373-424$ 
Criss RE, Gregory RT, Taylor HP Jr (1987) Kinetic theory of oxygen isotopic exchange between minerals and water. Geochim Cosmochim Acta 51:1099-1108

Demény A, Ahijado A, Casillas R, Vennemann TW (1998) Crustal contamination and fluid/rock interaction in the carbonatites of Fuerteventura (Canary Islands, Spain); a C, O, H isotope study. Lithos 44:101-115

Eiler JM (2001) Oxygen isotope variations of basaltic lavas and upper mantle rocks. In: Valley JW, Cole DR (eds) Stable isotope geochemistry. Rev Mineral Geochem 43:319-364

Farver JR (1989) Oxygen self-diffusion in diopside with application to cooling rate determinations. Earth Planet Sci Lett 92:356-396

Ferry JM, Mutti LJ, Zuccala GJ (1987) Contact metamorphism/ hydrothermal alteration of Tertiary basalts from the Isle of Skye, northwest Scotland. Contrib Mineral Petrol 95:166-181

Flagler PA, Spray JG (1991) Generation of plagiogranite by amphibolite anatexis in oceanic shear zones. Geology 19:70-73

Forester RW, Taylor HP Jr $(1977){ }^{18} \mathrm{O} /{ }^{16} \mathrm{O}, \mathrm{D} / \mathrm{H}$, and ${ }^{13} \mathrm{C} /{ }^{12} \mathrm{C}$ studies of the Tertiary igneous complex of Skye, Scotland. Am J Sci 277:136-177

Fúster JM, Cendrero A, Gastesi P, Ibarrola E, López Ruiz J (1968) Geología y Volcanología de las Islas Canarias: Fuerteventura. Instituto "Lucas Mallada", Consejo Superior de Investigaciones Científicas, Madrid, p 239

Gregory RT, Taylor HP (1981) An oxygen isotope profile in a section of Cretaceous oceanic crust, Samail ophiolite, Oman; evidence for $\delta^{18} \mathrm{O}$ buffering of the oceans by deep $(>5 \mathrm{~km})$ seawaterhydrothermal circulation at mid-ocean ridges. J Geophys Res 86:2737-2755

Harmon RS, Hoefs J (1995) Oxygen isotope heterogeneity of the mantle deduced from global ${ }^{18} \mathrm{O}$ systematics of basalts from different geotectonic settings. Contrib Mineral Petrol 120(1):95-114

Hobson A, Bussy F, Hernandez J (1998) Shallow-level migmatization of gabbros in a metamorphic contact aureole, Fuerteventura Basal Complex, Canary Islands. J Petrol 39(5):1025-1037

Hobson A, Bussy F, Hernandez J (2000) Migmatitic gabbros from a shallow-level metamorphic contact aureole, Fuerteventura Basal Complex, Canary Islands: role of deformation in melt segregation. In: Bagdassarov N, Laporte D, Thompson AB (eds) Physics and chemistry of partially molten rocks. Kluwer, Dordrecht, pp 209-227

Hoefs J (1997) Stable isotope geochemistry, 4th edn. Springer, Berlin, p 201

Hoernle K, Tilton G, Le Bas MJ, Duggen S, Garbe-Schönberg D (2002) Geochemistry of oceanic carbonatites compared with continental carbonatites: mantle recycling of oceanic crustal carbonate. Contrib Mineral Petrol 142:520-542

Holloway MI, Bussy F (2007) Trace element distribution among rock-forming minerals from metamorphosed to partially molten basic igneous rocks in a contact aureole (Fuerteventura, Canaries). Lithos (in press)

Javoy M, Stillman CJ, Pineau F (1986) Oxygen and hydrogen isotope studies on the Basal Complexes of the Canary-Islands-implications on the conditions of their genesis. Contrib Mineral Petrol 92(2):225-235

Kasemann S, Meixner A, Vennemann T, Schmitt A, Widenbeck M (2001) Boron and oxygen isotope composition of certified reference materials NIST SRM 610/612, and reference materials JB-2G and JR-2G. Geostand Newslett 25:405-416

Koepke J, Berndt J, Bussy F (2003) An experimental study on the shallow-level migmatization of ferrogabbros from the Fuerteventura Basal Complex, Canary Islands. Lithos 69(3-4):105-125

Le Bas MJ, Rex DC, Stillman CJ (1986) The early magmatic chronology of Fuerteventura, Canary-Islands. Geol Mag 123(3):287-298

Mevel C (1988) Metamorphism in ocean layer 3, Gorringe Bank, Eastern Atlantic. Contrib Mineral Petrol 100:496-509
Muehlenbachs K (1986) Alteration of the oceanic crust and the ${ }^{18} \mathrm{O}$ history of seawater. In: Valley JW, Taylor HP, O'Neil JR (eds) Stable isotopes in high temperature geological processes. Rev Mineral 16:425-444

Muñoz M, Sagredo J (1994) Reajustes mineralógicos y geoquímicos producidos durante el metamorfismo de contacto de diques basalticos (Fuerteventura, Islas Canarias). Bol Soc Esp Min 17(1):86-87

Nabelek PL (1991) Stable isotope monitors. In: Kerrick DM (ed) Contact metamorphism. Rev Mineral Min Soc Am 26:395-435

Roselle GT, Baumgartner LP, Valley JW (1999) Stable isotope evidence of heterogeneous fluid infiltration at the Ubehebe Peak contact aureole, Death Valley National Park, California. Am J Sci 299:93-138

Rumble D III, Hoering TC (1994) Analysis of oxygen and sulfur isotope ratios in oxide and sulfide minerals by spot heating with a carbon dioxide laser in a fluorine atmosphere. Acc Chem Res 27:237-241

Schmincke HU (1982) Volcanic and chemical evolution of the Canary Islands. In: von Rad U, Hinz K, Sarnthein M, Eugen S (eds) Geology of the Northwest African continental margin. Springer, Berlin

Sharp ZD (1990) A laser-based microanalytical method for the in-situ determination of oxygen isotope ratios of silicates and oxides. Geochim Cosmochim Acta 54:1353-1357

Stakes DS, Taylor HP Jr (2003) Oxygen isotope and chemical studies on the origin of large plagiogranite bodies in northern Oman, and their relationship to the overlying massive sulphide deposits. In: Dilek Y, Robinson PT (eds) Ophiolites in Earth history. Geol Soc Specl Publ, vol 218, pp 315-351, London

Stillman CJ (1987) A Canary Islands Dyke Swarm: implications for the formation of Oceanic Islands by extensional Fissural volcanism. In: Halls HC, Fahrig WF (eds) Mafic dyke swarms. Geol Assoc Can, Specl Paper 34:243-255

Stillman CJ, Fuster JM, Bennellbaker MJ, Munoz M, Smewing JD, Sagredo J (1975) Basal complex of Fuerteventura (CanaryIslands) is an oceanic intrusive complex with rift-system affinities. Nature 257(5526):469-471

Taylor HP Jr (1971) Oxygen isotope evidence for large-scale interaction between meteoric ground waters and Tertiary granodiorite intrusions, Western Cascade Range, Oregon. J Geophys Res 76:7855-7874

Taylor HP Jr, Forester RW (1979) An oxygen and hydrogen isotope study of the Skaergaard intrusion and its country rocks: a description of a 55-M.Y. old fossil hydrothermal system. J Petrol 20(3):355-419

Thirlwall MF, Jenkins C, Vroon PZ, Mattey DP (1997) Crustal interaction during construction of ocean islands: $\mathrm{Pb}-\mathrm{Sr}-\mathrm{Nd}-\mathrm{O}$ isotope geochemistry of the shield basalts of Gran Canaria, Canary Islands. Chem Geol 135(3):233-262

Valley JW (1986) Stable isotope geochemistry of metamorphic rocks. In: Valley JW, Taylor HP, O'Neil JR (eds) Stable isotopes in high temperature geological processes. Rev Mineral Min Soc Am 16:445-489

Valley JW (2001) Stable isotope thermometry at high temperatures. In: Valley JW, Cole DR (eds) Stable isotope geochemistry. Rev Mineral Geochem 43

Valley JW, Kitchen N, Kohn MJ, Niendorf CR, Spicuzza MJ (1995) UWG-2, a garnet standard for oxygen isotope ratios: strategies for high precision and accuracy with laser heating. Geochim Cosmochim Acta 59:5223-5231

Witt-Eickschen G, Seck HA, Mezger K, Eggins SM, Altherr R (2003) Lithospheric mantle evolution beneath the Eifel (Germany): constraints from $\mathrm{Sr}-\mathrm{Nd}-\mathrm{Pb}$ isotopes and trace element abundances in spinel peridotite and pyroxenite xenoliths. J Petrol 44:1077-1095 